\title{
The Impact of the Implementation of Financial Risks Management on the Disclosure Quality of Financial Reports
}

\author{
Ghalya Metlej ${ }^{1}$, Yahya Zalzali ${ }^{2} \&$ Mohamad Farhat ${ }^{3}$ \\ ${ }^{1}$ Jinan University, Tripoli, Lebanon \\ ${ }^{2}$ Head of the Accounting Department, Lecturer at the Islamic of Lebanon and lecturer at the lebanese University, \\ Lebanon \\ ${ }^{3}$ Head of the Accounting Department, Lecturer at the Lebanese University and Lecturer at the Islamic \\ University of Lebanon, Lebanon \\ Correspondence: Ghalya Metlej, Jinan University, Tripoli, Lebanon. E-mail: ghalyametlej@hotmail.com
}

Received: June 24, 2021

Accepted: July 26, 2021

Online Published: August 5, 2021

doi:10.5539/ijef.v13n9p61

URL: https://doi.org/10.5539/ijef.v13n9p61

\begin{abstract}
This study aims to demonstrate the impact of banking risk management on the quality of disclosure in the financial reports of a sample of Lebanese commercial banks by addressing the subject in its theoretical and practical framework and its relationship with internal and external auditing.

To achieve this goal, the study relied on the descriptive and analytical approach, and a sample of directors of the risk management department and directors of internal audit departments in the banks under study was selected, in addition to a sample of account auditors affiliated with the Association of Certified Public Accountants in Lebanon. For the purposes of statistical processing, appropriate statistical methods were used and the statistical analysis necessary to complete the current study was carried out, using the Statistical Package for Social Sciences (SPSS) program to process the data and extract the frequencies, arithmetic means and standard deviations according to the study page, and to test the study hypotheses at a significant level $(0.05 \geq \alpha)$.

The study found a positive correlation between the level of disclosure of financial risk and each of currency risk, interest risk, credit risk, market risk and operational risk, in addition to the existence of a close relationship between audit and risk management, and is reflected in the quality of disclosure so that the efficiency and effectiveness in banking work leads to controlling these risks and avoiding them in the future.
\end{abstract}

Keywords: financial risk management, internal audit, external audit, quality of disclosure in annual financial reports

\section{Introduction}

The banking industry has developed several times throughout history as a result of financial innovations and technological progress. In all countries, banks and financial institutions constitute the bedrock of the economy and business. The banking sector plays a vital and major role in the economic development process; on one hand, it mobilizes financial savings and directs them to targeted investments; on the other hand, the State applies its monetary system and financial policies through the said sector. The most important services provided by the latter are, inter alia, accepting deposits of all kinds, granting direct and indirect credit facilities, collecting and discounting commercial securities, issuing letters of guarantee, and opening documentary credits (Qarun, 2013).

With the increasing local and global competition, banks have become exposed to many risks arising from internal and external factors. In light of the escalation of banking risks, research for mechanisms to address such risks began. As a first step, Basel Committee on Banking Supervision was formed. It put in place a minimum capital adequacy ratio for the banks' funds and a minimum ratio for credit, market and operational risks, with the aim to reduce these losses and enhance the banks' financial position.

And since the financial sector generally deals with risks with reference to jobs, sectors, and economy mainly through banks, the bank shall deal with these risks in terms of form, type, and outcome (Sissi, 2014).

Given the importance of banking risk management in the field of banking and its primary role in reducing the risks faced by the banking system, Basel Committee on Banking Supervision put in place, in Basel 1 and Basel 2, 
three key pillars that became the international standards for banking work:

- $\quad$ Minimum capital requirements.

- Supervisory review of capital adequacy.

- $\quad$ Control and regulation of the market.

However, the American mortgage crisis in 2008 showed the limitation of this agreement, prompting the members of Basel Committee to issue Basel III in order to avoid future financial crises. Basel III raised the minimum capital adequacy to increase the banks reserves and raise banks capital.

In addition, the concept of audit quality is linked to the emergence of mandatory auditing. It can be described as "the auditor's ability to discover financial irregularities in applying the accounting system for the client and his/her ability to mention those violations in the report." (De Angelo).

The quality of auditing is an ongoing process. In fact, many recent studies called for the necessity of identifying the factors that affect the quality of auditors' work. (Reisch, 2000) confirmed that research and studies addressing the issue of audit quality are among the most important at both academic and practical levels.

\subsection{Objectives}

The failure experienced by some banks resulted in harming the depositors. It cast a shadow over the economic situation in general and banks in particular and created an environment of instability in the banking sector for a specific period. It is worth mentioning that these risks could have been reduced if the disclosure of financial risks in commercial banks was done in time with adequate quality.

Through this study, we will try to identify the levels of disclosure in financial reports. This disclosure can reduce financial and non-financial risks, given that these reports are relevant to all the parties in the economic equation, including investors, administrators, shareholders and creditors.

\subsection{Problem and Questions}

As a result of the economic openness of financial markets, interest in financial risk management increased largely in recent decades. It ensures the protection against external influences of mobile investments across countries. In light of the extreme fluctuations in interest rates, currency rates and stocks and bonds and in order to avoid wasting the great efforts deployed in this regard, laying the foundations of financial risks management for companies in general and banks in particular has become of considerable importance. On this basis, the following problem can be posed:

\section{- "To what extent does risk management affect the quality of financial reports in Lebanese commercial banks?"}

The following research questions can arise from this problem:

1) What is the role of risk management in developing the disclosure process of financial reports?

2) How does risk management help improve the quality of financial reports?

3) To what extent does annual financial reports of commercial banks in Lebanon include disclosure of credit risk, market risk, and operational risk?

\subsection{Hypotheses}

Given that the first two research questions are exploratory and need to be addressed according to the inferential approach and the qualitative research method, we developed hypotheses for the tripartite multi-view question in line with the need to use quantitative research methods to test the following hypotheses:

The first hypothesis:

- H1: There is a statistically significant relationship between credit risks and the quality of disclosure in the annual financial reports.

- H0: There isn't a statistically significant relationship between credit risks and the quality of disclosure in the annual financial reports.

The second hypothesis:

- H1: There is a statistically significant relationship between operational risk and the quality of disclosure in the annual financial reports.

- H0: There isn't a statistically significant relationship between operating risks and the quality of disclosure in 
the annual financial reports.

\subsection{Importance of the Study}

The importance of the study revolves around the role of banking risk management in a world where the banking industry is constantly developing and risks are multiplying. Therefore, developing and paying close attention to risk management processes can lead to maximize the banks' returns and avoid financial crises. Accounting standards and disclosure standards of financial reports have imposed levels of disclosure on companies in general and banks in particular to keep pace with the development of banking business in terms of safety, return and liquidity and to mitigate the manipulations of the results of banks' business.

Accordingly, the Basel Committee on Banking Supervision has set unified standards for capital adequacy. The latter increases the effectiveness and efficiency of banking risk management and helps Lebanese banks adopt effective risk management to avoid and control risks in the current situation and face the American measures (FATCA and Caesar Law) and the associated sanctions on Lebanese banks.

\section{Financial Reports, Quality of Disclosure, Disclosure Requirements}

\section{Through the following topics:}

1) Financial Reports, Qualitative Characteristics of Financial Reports.

2) Quality of accounting disclosure of financial risks.

3) Disclosure of risks according to the requirements of the Central Bank, accounting standards, and Basel III decisions.

\subsection{Financial Reports}

Recently, the financial and accounting sciences have developed significantly, especially with the use of advanced electronic means, the expansion of financial globalization, and many other factors. All these factors shed a light on the necessity of information flow within specific frameworks, as it helps in making economic, political, administrative and financial decisions in a timely manner. The said information emerge from the accounting systems adopted by companies and institutions of all sorts. To achieve it aim, the information must enjoy some characteristics that make the process highly reliable and beneficial These characteristics are stipulated by stipulated by international accounting standards and they include reliability, comparability and understandability. They take into consideration the diversity of benchmarks between countries, sectors and even companies operating in the same field, which can mislead decision-makers at times. Consequently, International Financial Reporting Standards (IFRS) was developed and adopted. Most organizations and countries adopt the IFRS to avoid the impact of systems diversity, especially with the increasing impact of globalization, foreign trade and banking operations outside the counties' borders.

The reasons that contributed to the adoption of the International Financial Reporting Standards are the following:

- Economic globalization and the liberalization of foreign trade.

- Opening up of financial markets worldwide.

- The changes in global monetary systems.

- The spread and expansion of multinational companies.

- The growth of privatizations and the shrinking role of central states in economic activity.

- The spread of holding companies and their control over some companies in more than one country.

Accounting is the language of business, and it is the translation of decision-making (Abu Nassar \& Jumah, 2008, pp. 75-82). Financial reports contain financial and non-financial information, reports addressed to the board of directors and recommendations that help with appropriate and timely decision-making. They are prepared and drafted within limits set by organizations and institutions that seek to draft and present financial statements. The quality of these reports represents the primary criterion in the decision-making process.

\subsubsection{Financial Reporting and International Accounting Standards}

The main function of accounting revolves around providing information to the users inside and outside the organizations. Financial reports aim at providing decision-makers with information to help them determine the organization's ability to achieve profits and expand in the markets and secure new cash flows. It also contains information about the financial position of the organization in general. According to the International Accounting Standards (IAS), financial statements include: 
- Balance Sheet.

- Income Statement.

- Cash flow Statement.

- Changes on Equity Statement.

- Accounting Policies and explanatory notes.

Financial statements aim at providing information about the financial situation and financial changes of the organization. They help a wide range of users make their economic decisions. Consequently, meeting the users' needs ensures their satisfaction and help with reaching the following objectives: (IFRS, 2018, 643-678)

- Providing useful information to estimate cash flows and cash flows periods.

- Presenting the financial position and obligations of the institution and the impact of the operations and occurrences in changing the resources and obligations.

- Highlighting ways of creating and spending liquidity in operational activities and financing investments and the institution's ability to fulfill its obligations.

- Presenting information about the strategies adopted by managers to achieve the goals.

The balance sheet presents information about the financial position of the organization at a specific moment: Result calculations show the performance of the organization during the financial year; cash flow schedule shows the movement of cash flow during the financial year, as well as the cash balances inventories.

\subsubsection{Components of Financial Reports}

- A summary of the most important elements presented in the income statement.

- A report from the board of directors or the general manager to shareholders presenting the company's goals, strategies and achievements.

- Administration report about the role it plays and the accuracy and integrity of the financial statements.

- Auditor's report on the fairness and accuracy of the financial statements.

- Presentation of financial statements.

The laws and regulations determine the forms and content of the annual financial reports prepared by companies. For instance, In USA, financial reports must include the managerial decisions, a debate about operational results, liquidity, sources of capital and reasons for changes occurring in profit and risks. (Roman L, 2010, 7).

\subsubsection{Financial Reporting Objectives}

The interaction of information with the process of accounting auditing forms the financial statements, therefore, there are three approaches to formulate its objectives:

- What information does the company want to disclose and what are the best information measurement and verification methods?

- What information can be verified and measured by the accounting profession, and what is the appropriate compendium that guarantees the rights of all the parties?

- What is the accounting information that have a major relationship with the decision-making process as per information users?

This approach is adopted by both the IASB and the FASB to determine the objectives of financial reports. it is necessary:

- To provide useful financial information about the current and potential investors and assist the investors in making decisions related to buying, selling or acquiring equity and debt instruments.

- To provide information conductive to predictability.

- To provide information about the financial position of the company preparing the report.

- To provide information on the financial performance of the company during the financial cycle.

- To provide information on changes in economic resources, and the non-monetary operations of the company.

- To provide information on how the company obtains and deals with cash flows. 
"The financial reports shall provide useful information and the investor must take into account that these financial reports are not invariable, but rather change according to the economic influences." (IFRS, 2018, pp. 643-678).

\subsubsection{Quality of Financial Reports}

The quality of financial reports emerges from the ability of providing decision-makers with the needed information and reducing the uncertainty in making decisions. (Abu Hammam, 2009, p. 55).

The American Association of Certified Public Accountants (AACPA) defines reporting quality as "the ability to use information in predictions processes and adapting information to achieve the set goals."

The term quality in financial reports expresses the criteria that make the financial information useful in the process of decision-making. (Hamada, 2013, p. 682).

Whenever financial reports are free from material misstatements, they provide a fair landscape of the integrity and accuracy of financial statements. This leads to increased predictability and good decision-making, which achieves the goals of the organizations (Hamdan, 2011, p. 418).

For quality to be achieved in financial reports, the latter must contain the following characteristics:

- Understandability.

- Relevance.

- Reliability.

- Honest representation.

- The essence is above the form.

- Impartiality.

- Caution.

- Completeness.

- Comparability.

- $\quad$ Timing. (International Accounting Standards, 2018)

For the information in financial reports to be useful, it shall be convenient and shall help in predicting the future and the organization's ability to exploit the available opportunities. The information is considered relevant when it can impact the decision making. The predictive value of the information reflects its relevance. Relevance revolves around three elements:

- Prediction.

- Evaluative value.

- $\quad$ Timing.

The availability of qualitative characteristics in financial reports leads to achieving the aim of accounting information as they help with making sound decisions. However, there are limitations to this information that mainly lies in cost-benefit considerations and materiality. These limitations may sometimes refrain from implementing of a particular accounting standard as per these considerations (International Accounting Standards, 2018).

\subsubsection{Financial Reports in the Lebanese General Accounting System}

The Lebanese Public Accounting system in Decree No. 4665 issued on December 26, 1981 states in its General Principles the financial reports and disclosures and their goal; and defines it as "reflecting an unvarnished picture regarding the results of the recorded transactions, the net shareholders' equity and the financial position thereof." Article 4 specifies the common accounting principles:

- The principle of nominal value or historical cost.

- The principle of independence of the financial cycle.

- The principle of consistency in the use of evaluation methods.

- The principle of precaution.

- The principle of investment continuity.

- The usefulness of information for decision-makers. 
For the objectives of the financial reports to be achieved, it is necessary to:

- Honestly express the financial position of the facility and the results of its business.

- Provide a reliable guide to measure the performance of the facility's economic activities.

- Provide the external auditors with a comprehensive and fair basis in the evaluation process. (Wehbe, 2008, p. 34).

\subsection{Quality of Financial Risk Disclosure}

\subsubsection{Standards of Financial Risks Accounting Disclosure Quality}

Companies in general, and banks in particular, face many risks due to technological development, the expansion of financial globalization, and certainty in estimating these risks. These risks were addressed by the International Financial Reporting Standard IFRS 7 (Financial Instruments - Disclosures), which defined the types of banks risks as Follows:

- Credit risk: when one party causes a financial loss to the other party by failing to pay its obligations.

- Liquidity risk: when banks face difficulty in meeting their obligations.

- Market risk: when the fair value or future cash flows of a financial instrument changes due to a change in market prices. Market risk includes three types of risks:

- Currency rate risk: when foreign exchange rates change.

- Interest rate risk: when interest rates in the market change.

- Other price risks: when market prices change.

The financial risks that banks face can be controlled through effective risk management. This management helps the bank reach its objectives in terms of achieving profit and reducing risks.

The disclosure of financial risks helps the parties who are dealing with the bank with taking appropriate investment decisions, which would reflect a positive image on the bank's reputation, credibility and transparency (Jizi \& Dixon, 2017, pp. 7-30).

IFRS 7 stressed the need to disclose both quantitative and descriptive risks. In fact, the interaction between the two provides decision-makers with information that help them assess risks more accurately. The legislation passed in the USA forced commercial banks to implement the legislation issued by the Stock Exchange regarding the rules of disclosure. It has resulted in widely changing the disclosure of the balance sheets of American banks in terms of:

- Expanding the scope of the disclosure to include information that was considered taboo.

- Shifting the disclosure objectives from protecting the interests of depositors to protecting shareholders and investors (Abu Zeid, 2011, p. 490).

The American Institute of Certified Public Accountants (AICPA) defined the accounting disclosure as:

"Presenting the financial statements clearly and in accordance with accepted accounting principles". This relates to the form of the information contained in the financial statements, its classification and the meanings of the terms contained therein.

The accounting disclosure reduces the uncertainty and widening these markets and increasing the offered shares, and thus, increasing the trading volume (Al-Sabban et al., 2013, p. 9).

\section{Disclosure usually takes place within two criteria:}

A- The ideal disclosure: that is used when the financial reports contain the smallest details.

B- Realistic disclosure: differentiating between the desired benefit and the ability to rely on it.

2.2.2 Types of Accounting Disclosure

There are several types of disclosure, the most prominent types are:

- Full disclosure.

- Fair disclosure.

- Adequate disclosure.

- Appropriate Disclosure. 
- $\quad$ Preventive disclosure.

- Media disclosure.

Disclosure is of great importance in the banking sector. Therefore, it is inevitable to reach an integrated framework for the disclosure of financial risks, based on the relative importance of these risks on one hand, and the need of decision-makers who use these reports on the other hand. Consequently, published financial reports must reflect all risks and the ways to manage them. The level of disclosure shall be comprehensive and sufficient to help users better understand the nature of those risks. Such disclosure helps all the parties dealing with the bank to take early measures.

\subsection{Disclosure of Banking Risks under the Requirements of the Central Bank, Accounting Standards and Basel} III

The banking sector is known for the risks it is exposed to. This has prompted the official and legal authorities around the world to find standards that define and regulate work in this sector, to avoid falling into possible problems. Among the bodies working on the matter, we mention central banks, international accounting standards, and the Basel Committee (Alvin \& James, 2010).

\subsubsection{Disclosure of Risks According to the Requirements of the Central Bank}

After the issuance of the International Financial Reporting Standard IFRS 9, the Central Bank (Banque du Liban) and the Banking Control Commission issued the Memorandum No. 18/2015 addressed to banks and financial institutions in Lebanon, under the title "Implementation of the International Financial Reporting Standard IFRS 9". This document referred to the three criteria of classifications:

A- Classification and measurement.

B- Addressing the decline in the value of assets.

C- Hedge accounting.

This standard came into effect as of 01/01/2018, and it imposed:

1) Stipulating provisions on financial assets and liabilities.

2) Collecting information and developing the necessary management information systems.

The Central Bank asked all banks and financial institutions in Lebanon to prepare for the implementation of the requirements of IFRS 9 in coordination with their accredited auditors, and to adhere to the stages specified in the memorandum:

- Forming an internal work team: within a period specified in the memorandum 9/30/2015.

- Developing a detailed plan to implement the standard at the group level not later than 12/31/2015.

- Developing a measurement concept: the expected credit losses of the financial assets and liabilities concerned with this standard inside and outside the budget over 12 months.

The Banque du Liban set time limits ending on 12/31/2015 through which all stages of the memo shall be completed. Completing these steps is considered as an early and prior preparation for the actual start of the mandatory implementation.

The early interest of Banque du Liban took shape with the Basic Resolution No. 7493 related to financial operations, in which the central bank requested the following from the Lebanese banks:

- When conducting SWAP operations on financial instruments, whether they were of the same type or not, and whether the operations were done directly between banks and financial institutions, or with the same broker or with different brokers, the following requirements must be followed:

- Observe the de-recognition conditions stipulated in Section 3 of IFRS 9 if these operations lead to an effective transfer of all risks associated with the sold instruments.

- The sale operations take place in accordance with the market rules and at the prevailing prices (ie the market price).

- The sales operations shall be from a portfolio of financial securities (instruments) classified (at amortized cost), consistent with the business model and adhering to the terms of sale stipulated in IFRS 9.

And other paragraphs related to IFRS 9, which indicates the interest of Lebanese banks in the experimental and retrospective implementation of IFRS 9 from an early stage. (Banque du Liban, Banking Control Commission, 
Memorandum No. 18/2015).

\section{All banks must disclose each type of risk resulting from financial instruments:}

- The possibility of the bank being exposed to risks and how those risks arise.

- What are the objectives, procedures and policies of the bank for risk management?

- Summaries of financial data and reports related to risks according to the degree of accuracy and comprehensiveness of this information.

- Accurate characterization of common characteristics regarding risk management.

2.3.2 Disclosure of Financial Risks under the Requirements of International Accounting Standards

The implementation of accounting standards at the international level greatly contributes to improving and developing the quality of information contained in these financial reports, provided that the information enjoys the required integrity and credibility. Such implementation also makes this information comparable to organizations operating in the same field. Banks are required to prepare financial statements in accordance with International Accounting Standard No. 30, which "relates to disclosure in the financial statements of banks and similar financial institutions". IAS 30 has been repealed and replaced by IFRS 7 (Financial Instruments Disclosures).

2.3.3 Disclosure under the Requirements of IAS 30 (Disclosure in Financial Statements of Banks and Similar Financial Institutions)

The following shall be disclosed according to the requirements of this standard:

- The value and nature of the commitment relating to the provision of irrevocable credit.

- The value and nature of contingent commitments arising from off-budget commitments. (Futures contracts, banking facilities ... etc.).

- Disclosure of the maturity of assets and liabilities, classifying them according to the balance in the balance sheet, and detailing and distributing the installments over periods according to the method and duration of payment.

- Disclosure of assets and off-balance sheet items.

- Disclosure of loans and advances granted, specifying the associated expenses, and how to make provisions and doubtful loans.

- Disclosure of any amounts allocated to face banking risks.

- Disclosure of the pledged assets or as a guarantee, the mortgage value, and the book value of the asset.

- Disclosure of transactions with related parties regarding loans, deposits, advances, bills of exchange, deposited amounts, provisions allocated to meet losses resulting from these amounts, types of revenues and irrevocable commitments resulting from off-budget commitments.

\section{Disclosure under the requirements of Financial Reporting Standard IFRS 8 Operating Segments:}

Disclosure should be made according to the requirements of this standard as follows:

- Information on external customers revenues for each product or service.

- Information on foreign countries for each category of revenue according to the country from which the revenue is generated.

- Information on major customers (if the revenue generated from transactions with a single external customer is equal to $10 \%$ or more of the institution's revenue).

\section{Disclosure of financial risks under the requirements of Basel Committee:}

The decisions of the Basel Committee require the creation of an organized environment to help implement banking and financial laws and legislation and deal with customers with transparency and credibility. The disclosure should be comprehensive of all information that would influence the investment decision-making process. Banks are forced to publish information clearly and with high credibility, especially related to the expected risks, and to disclose the procedures and means used to confront these risks, provided that publication is done in a way that enables everyone to obtain data in a timely manner.

\section{Risk disclosure requirements under with Basel II:}

Basel II dealt with disciplining and stabilizing markets, leading banks to conduct their business in a safe, sound 
and effective manner and to face the expected losses resulting from risks, with the aim of strengthening the safety and security of the banking sector. In order to estimate the size of the required capital, Basel Committee defined the elements required to be disclosed according to Basel II as follows:

- $\quad$ Capital structure

- $\quad$ Credit risk.

- Long-term investment risks.

- Market risk.

- Ways to measure and avoid risks

- Basel III added to the foregoing liquidity risk.

- The implementation of the decisions of the Basel Committee would lead to the improvement of disclosure and transparency systems, increasing the accuracy of risk measurement and improving liquidity management, which would be reflected in the effectiveness of the banking system.

- The banks' disclosure of credit risks under the Basel II agreement is in accordance with International Accounting Standard IAS 30 concerning the disclosure of amounts to face loan losses and lending operations. (Abdul-Samad, 2008, p. 221).

\section{Basel III risk disclosure requirements:}

- Credit risk: The third pillar of the Basel III agreement related to market discipline requires banks to disclose credit risks by providing a comprehensive description of the bank's objectives, the credit risk management policies, the risks measurement mechanisms and the methods and policies used to reduce these risks.

- Banks must ensure that the disclosure of credit risk is done through quantitative and qualitative disclosure: (Basel Committee on Banking Supervision, 2015, pp. 18-24).

\begin{tabular}{ll}
\hline Disclosure of credit risk & \\
\hline Qualitative Disclosure & Quantitative Disclosure \\
\hline The bank's policy in managing credit risk. & Disclosure of loans exposed to default risk \\
Disclosure of loan maturity dates. & Disclosure of the amounts exposed to risks \\
The methods used to determine the risks. & Information on risk re-evaluation. \\
Permits granted to customers & \\
\hline
\end{tabular}

Market risk: Banks shall disclose the objectives and strategies concerning market risks by explaining the bank's management strategy in commercial activities and operations and the accompanying risks. It shal also disclose a description of the approved market risk management structure adopted to accomplish the bank's strategies. What are the systems for identifying and measuring risks followed in the bank? (Basel Committee on Banking Supervision, 2016, pp. 75-77).

Operational risks: Banks must disclose the policies and guidelines used in managing, regulating and managing operational risks, the scope of reports issued about them and the approved ways to reduce these risks. (Basel Committee on Banking Supervision, 2016, p. 83).

\begin{tabular}{ll}
\hline Disclosure of operational risks & \\
\hline Qualitative Disclosure & Quantitative Disclosure \\
\hline Determine the measurement method used for risk. & Indicate all costs related to operational risks before and \\
Methods of assessing operational risks. & after any reduction resulting from the use of the \\
The insurance methods used to reduce these risks. & insurance policy. \\
\hline
\end{tabular}

Liquidity risk: Despite the importance of liquidity risk in banking, Basel II did not mention among the banking risks to be exposed.

The bankruptcy of some banks due to poor liquidity management exacerbated the global financial crisis in 2008 . Therefore, Basel III Committee approved several new standards in order to improve the ability of the banking system to face crises through 1- Increasing capital ratios and reserves, 2- Setting new standards concerning liquidity that helps banks face risks, 3- strengthen the ability to face the liquidity crisis and limit its impact, 4enhance transparency and disclosure in financial reports, 5- provide sufficient and comprehensive information 
for users of financial statements to make appropriate investment decisions. (Basel Committee on Banking Supervision, 2016, p. 65).

\begin{tabular}{ll}
\hline Disclosure of market risk & \\
\hline Qualitative Disclosure & Quantitative Disclosure \\
\hline Ability to take risks. & Methods and tools for measuring the bank's cash flows. \\
Liquidity risk strategies. & Future liquidity. \\
Liquidity risk management responsibilities. & Guarantees and funding sources. \\
Liquidity risk financing and management strategies. & Determine the liquidity risks \\
Approved methods to reduce liquidity risk. & \\
\hline
\end{tabular}

Banks shall adhere to the rules of the Central Bank, International Accounting Standards and the decisions of the Basel Committee while disclosing risks. They shall work to provide appropriate clarifications in the event of a dispute or conflict between the accounting disclosure and the disclosure in accordance with the requirements of the Basel Committee and International Accounting Standards. In this context, the Central Bank and International Financial Reporting Standard No. IFRS 7 (Financial Instruments - Disclosures) forced banks to disclose all of the credit risks, market risks and liquidity risks, while the Basel II agreement required disclosure of credit risks, market risks, and operational risks, and ignored the disclosure of liquidity risk despite its importance, given that it was the cause of the global financial crisis in 2008. Accordingly, Basel III Committee requested the disclosure of credit risk, market risk, liquidity risk and operational risk.

\section{Statistical Analysis of the Field Study}

The study aims to confirm the basic assumptions established by the study through a questionnaire prepared and assessed by three academics professors. A group of closed questions was developed, with a one-word answer.

To test a set of hypotheses, the two researchers resorted to a direct investigation method. A questionnaire was prepared to identify the opinions of specialists in this field and was distributed to the two main parties in the matter consisting of Certified Accountants registered to the Association of Accounting Experts in Lebanon, the Department of Risk Management and Internal Auditing of a commercial bank in Lebanon.

\subsection{Study Approach}

This study adopts the descriptive-analytical approach for its relevance with the study, and as it is one of the most widely used approaches that study social and human phenomena. The concept of the descriptive-analytical method is defined as "an approach realistically describing a phenomenon, without the contribution of the researcher with his/ her endeavours".

\subsection{Steps to Build a Search Tool}

The researchers distributed the questionnaire to a small group to test its quality and see if it is understandable, comprehensible, relevant and sufficient to collect the required information on the research topic and its problem. The observations made by these participants in the exploratory study were taken into account. This process is called validity, (Gay, 2012, p. 160) defined it as "the degree to which the test can measure and the meaning behind its measurement. In other words, the test is valid for a specific purpose for a particular group."

\subsection{Study Population}

The study population consists of a group of accountants, auditors and some managers in the Risk Management and Internal Audit Department of a commercial bank in Lebanon. The following is a table detailing the study population, by numbers and percentages of the respondents.

Table 1. Study population

\begin{tabular}{lcc}
\hline Description & Number & Percentage \\
\hline Total accounting experts in the governorates of Mount Lebanon and Beirut & 1712 & $\% 89.5$ \\
Sections of risk management in the sample of commercial banks & 100 & $\% 5.25$ \\
Department of Internal Auditing in the sample of commercial banks & 100 & $\% 5,25$ \\
Total population of the study & $\mathbf{1 9 1 2}$ & $\mathbf{1 0 0 \%}$ \\
\hline
\end{tabular}

Source: Prepared by researchers based on the numbers that responded to the study.

\subsection{The Study Sample}

Robert Masson's equation was used to determine the sample size from a population of 1912. Mason's equation 
shows that the appropriate sample size for the study population equals 320 . Accordingly, the form was distributed to a random sample of 320 persons from the total population of the study. 303 valid forms were retrieved for analysis. This number is considered sufficient for conducting statistical analysis and reach the objectives of the study.

Robert Mason's equation for calculating sample size,

\section{Whereas:}

$$
n=\frac{M}{\left[\left(S^{2} \times(M-1)\right) \div p q\right]+1}
$$

\begin{tabular}{ll}
\hline $\mathbf{M}$ & size of the community \\
$\mathbf{S}$ & Divide the standard score corresponding to the significance level 0.95 , i.e., divide 1.96 by the error rate 0.05 \\
$\mathbf{P}$ & is the ratio of availability of the property of 0.50 \\
$\mathbf{Q}$ & The residual ratio of the property is 0.50 \\
\hline
\end{tabular}

Source: Prepared by the researcher based on Robert Mason's equation.

\subsection{Validity and Stability Test}

The stability coefficient highlights the stability and non-contradiction of the scale. It gives the same results if it is re-applied to the same sample. The Alpha Cronbach parameter was used to test the reliability of the questionnaire. The values in this parameter range from zero to one. If there is no consistency in the data, the value of the coefficient reaches zero, and on the contrary, if there is complete constancy, the value of the coefficient reaches one.

The more the is close to one, the more it is stable; the less it is close to zero, the less it is stable.

In order to confirm the validity, strength and coherence of the questionnaire, a group of experts in the Faculty of Economic Sciences and Business Administration at the Lebanese University, and the Faculty of Economics and Business Administration at the Islamic University in Lebanon suggested some amendments to the form. Based on their recommendations, the required amendments were made and the questionnaire was distributed to the sample.

\section{The main points of the questionnaire:}

The main axis of the questionnaire and the number of paragraphs for each axis were determined as in the following table:

Table 2. The study population

\begin{tabular}{lc}
\hline Axis & Number of paragraphs \\
\hline Axis related to demographic questions & 9 \\
First axis: Lebanese banks apply quality standards in disclosing credit risk. & 8 \\
Second axis: Lebanese banks apply quality standards in disclosing operational risks. & 7 \\
\hline
\end{tabular}

Source: prepared by researchers based on the questionnaire.

The questionnaire is divided into two parts: the first section deals with demographic information about the study sample. The second part, which is the field section, was divided into three axes.

\section{Statistical data processing:}

The goal of any research is to reach accurate scientific results and address the issue or issues raised. This is done through collecting, tabulating, analyzing and interpreting data in scientific ways. This path leads to answering the questions posed at the beginning of the research and answering the formulated hypotheses to express the strength or weakness of the relationship between risk management and the quality of disclosure in financial reports.

The results of the questionnaire were analyzed by the statistical package program known as SPSS, (Statistical Package for Social Sciences). This program can deal with almost all types of data and is known for its superiority in descriptive statistics, basic regression analysis, and analysis of variance ... etc.

\section{The statistical concepts used in the study:}

Likert Scale was used to obtain the answers according to the degrees of approval. This scale gives a score for each of the previous measurement statements as shown in Table 3. 
Table 3. The measurement values used in the five-fold Likart scale

\begin{tabular}{cccccc}
\hline Approval Degree & Totally agree & Agree & Neutral & Disagree & Strongly Disagree \\
\hline Weight & 5 & 4 & 3 & 2 & 1 \\
\hline
\end{tabular}

Source: Prepared by researchers based on the questionnaire.

The scores were given to the answers as shown in Table 3. In order to determine the categories of the five-point Likert Scale, the range was calculated by subtracting the upper bound from the lower bound $(5-1=4)$, and then dividing the answer by the largest value in the Scale $(4 \div 5)=0.80$. This value was added to each value in the Scale, to determine the maximum and the minimum for this category, and so, the value of the categories range as shown in Table 4:

Table 4. Correction of the five Likert scale categories

\begin{tabular}{llcc}
\hline Number & Answer & \multicolumn{2}{c}{ Class limits } \\
\cline { 3 - 4 } & & From & To \\
\hline 1 & Totally agree & 4.21 & 5.00 \\
2 & Agree & 3.41 & 4.20 \\
3 & Neutral & 2.61 & 3.40 \\
4 & Disagree & 1.81 & 2.60 \\
5 & Strongly Disagree & 1.00 & 1.80 \\
\hline
\end{tabular}

Source: prepared by researchers based on (SPSS) program.

\section{Honesty and persistence:}

We seek to measure the certainty and validity of each element of the scale by checking if it would give the same results when applied to the same sample at a later period.

To determine the stability of measuring instrument, the Alpha Cronbach parameter was adopted. The Alpha Cronbach coefficient is calculated by aligning the result for each scale element with the net result of each observation. We underscored the following:

The minimum coefficient should be higher than 0.65 to confirm the reliability of the results (Goforth, 2015). Regarding this problem, Dornyei stated, that "the result of Alpha Cronbach coefficient is expected to be rather low, but even with the presence of low points from 3 to 4 , we must aim for reliability coefficients that exceed 0.70, if the Alpha Cronbach Scale does not reach a Scale of 0.60 then this should be a warning. (Dornyei, 2003, p. 112).

\section{Results of honesty and reliability:}

The following table shows the results of reliability test with the results obtained from the number of elements and Alpha Cronbach coefficient in the questionnaire:

Table 5. The Cronbach alpha-test for the general form

\begin{tabular}{lcc}
\hline Axis & Phrases number & $\begin{array}{c}\text { Persistence factor } \\
\text { Alpha Cronbach }\end{array}$ \\
\hline First axis: Lebanese banks apply quality standards in disclosing credit risk. & 8 & 0.826 \\
Third axis: Lebanese banks apply quality standards in disclosing operational risks. & 7 & 0.748 \\
The questionnaire as a whole & 22 & $\mathbf{0 . 9 3 2}$ \\
\hline
\end{tabular}

Source: prepared by researchers based on (SPSS) program.

We can see from Table 5 that the coefficient of stability in the Cronbach alpha method reached 0.748 for the "Quality Standards for Disclosure of Operational Risks" axis and 0.826 for "Quality Standards in Disclosure of Interest Rate Risk" axis, while the value of p-value for Cronbach reached 0.932 for the whole questionnaire, which is considered a high value for Alpha Cronbach.

\section{Statistical tests:}

The statistical tests that were adopted to examine the variables related to study are:

- Descriptive Statistics: It aims to describe, classify and summarize a group of data and present it clearly in 
tables or graphs and calculate statistical measures to describe one or more variables in a community. (Todd, 2007).

- T test (T-Test): The "T" test is one of the most commonly used significance tests in social and educational research. It measures the differences significance between related and unrelated averages to equal and unequal samples. (William, 1992).

- ANOVA: Anova is method used to find out if the results of a survey or experiment are relevant. It helps you reject the null hypothesis or accept the alternative one. Basically, it allows you to test different groups to see if there is any difference between them. ANOVA is divided into:

- One Way ANOVA: A one-way ANOVA is used to compare two arithmetic means from two independent (not correlated) groups using the F-distribution. The null hypothesis of the test is that the two averages are equal.

- Two-way ANOVA: Two-way ANOVA is an extension to the one-way ANOVA. One Way Anova comprises one independent variable affectig the dependent variable, while Two-way ANOVA comprises two independent variables. The two-way ANOVA method is used when there are one measurement variable (i.e. a quantitative variable) and two nominal variables. If the particular experiment has a quantitative result and we have two categorical independent variables, then the two-way ANOVA is suitable. (Gerald van, 2008).

- Kruskal-Wallis test: This test is based on a median comparison of each group. It also depends on arranging the results in ascending order to determine the rank for each outcome. Moreover, this test assumes that all results have the same continuous statistical distribution, but the location parameters of each group may differ and that they are independent and do not depend on each other. Through these tests, the degree of statistical significance, which ranges between 0 and 1, can be compared with an estimated margin of error of 0.05 . If the degree of statistical significance is greater than the margin of error, there is no effect of the independent variable on the dependent variable, and vice versa.

\subsection{Results of Statistical Tests}

The test results were divided into two parts: the first section deals with the demographic results, and the second section deals with the statistical analysis of the questionnaire.

\subsubsection{Analyzing the Demographic Results}

The demographic results include characteristics related to the ages and sex of the sample, and the characteristics that determine years of experience, academic qualifications, and the nature of work for the sample. The demographic results were as follows:

From Table 6, We will know the gender of the sample as follows:

Table 6. The sex distribution of the sample

\begin{tabular}{lcccc}
\hline Gender & Frequency & Percent & Valid Percent & Cumulative Percent \\
\hline Male & 183 & 60.3 & 60.3 & 60.3 \\
Female & 120 & 39.7 & 39.7 & 100.0 \\
Total & $\mathbf{3 0 3}$ & $\mathbf{1 0 0 . 0}$ & $\mathbf{1 0 0 . 0}$ & \\
\hline
\end{tabular}

Source: prepared by researchers based on (SPSS) program.

Table 6 shows that the males percentage in the questionnaire was $60.3 \%$, while the percentage of females was $39.7 \%$. The difference between these percentages did not change the quality of the statistical tests.

Table 7 shows the ages of the respondents who were included in the study sample:

Table 7. Age distribution of the respondents

\begin{tabular}{lcccc}
\hline & Frequency & Percent & Valid Percent & Cumulative Percent \\
\hline More than 50 years & 63 & 20.8 & 20.9 & 20.9 \\
Between 40 and 50 years & 134 & 44.2 & 44.4 & 65.2 \\
Between 30 and 40 years & 91 & 30.0 & 30.1 & 95.4 \\
Less than 30 years & 15 & 4.6 & 4.6 & 100.0 \\
Total & $\mathbf{3 0 3}$ & $\mathbf{1 0 0 . 0}$ & $\mathbf{1 0 0 . 0}$ & \\
\hline
\end{tabular}

Source: prepared by researchers based on (SPSS) program. 
Answers from external auditors and Risk management and internal audit staff were distributed as follows as per table 7:

Respondents younger than 30 years old accounted for $4.6 \%$, while the percentage of respondents whose ages range between 30 and 40 years reached $30.1 \%$. As for the respondents whose ages range between 40 and 50 years, the percentage was $44.4 \%$, and the percentage of the respondents older than 50 years old reached $20.9 \%$.

This diversity in ages indicates that the account auditors and Risk management and internal audit staff in banks are mostly young people. Respondent older than 50 years old are competent and experienced and the category younger than 30 years represent the continuity in the field.

Table 8 shows the academic qualifications of the respondents who were included in the study sample:

Table 8. Scientific qualification

\begin{tabular}{lcccc}
\hline & Frequency & Percent & Valid Percent & Cumulative Percent \\
\hline Bachelor & 136 & 44.9 & 44.9 & 44.9 \\
Masters & 128 & 42.2 & 42.2 & 87.1 \\
Doctorate & 38 & 12.5 & 12.5 & 99.7 \\
Others & 1 & 0.3 & 0.3 & 100.0 \\
Total & $\mathbf{3 0 3}$ & $\mathbf{1 0 0 . 0}$ & $\mathbf{1 0 0 . 0}$ & \\
\hline
\end{tabular}

Source: prepared by researchers based on (SPSS) program.

Table 8 shows that $(44.9 \%)$ of the sample are holders of a bachelor degree, $(42.2 \%)$ are holders of master's degree, and (12.5\%) hold a PhD.

Table 9 shows the specialization of the respondents included in the study sample:

Table 9. Scientific specialization

\begin{tabular}{lcccc}
\hline & Frequency & Percent & Valid Percent & Cumulative Percent \\
\hline Accounting & 207 & 68.3 & 68.3 & 68.3 \\
Banks \& Finance & 42 & 13.9 & 13.9 & 82.2 \\
Business Administration & 47 & 15.5 & 15.5 & 97.7 \\
Others & 7 & 2.3 & 2.3 & 100.0 \\
Total & $\mathbf{3 0 3}$ & $\mathbf{1 0 0 . 0}$ & $\mathbf{1 0 0 . 0}$ & \\
\hline
\end{tabular}

Source: prepared by the researcher based on (SPSS) program.

The percentage of people with an accounting degree reached $68.3 \%$, most of them are external auditors affiliated with the Lebanese Association of Certified Public Accountants and internal auditors in banks. $13.9 \%$ of the sample hold a degree in banking and finance and are engaged in the banking business. $15.5 \%$ hold a degree in management, they perform administrative work inside banks. A very small percentage of $2.3 \%$. did not mention their specialization, which indicates that the resondents are specialists in the relevant field.

Table 10 shows the current job of the respondents:

Table 10. Current position

\begin{tabular}{lcccc}
\hline & Frequency & Percent & Valid Percent & Cumulative Percent \\
\hline Director Department & 77 & 25.4 & 25.6 & 25.6 \\
Internal Auditor & 96 & 31.7 & 31.9 & 57.5 \\
External Auditor & 104 & 34.3 & 34.6 & 92.0 \\
Others & 26 & 8.5 & 7.9 & 100.0 \\
Total & $\mathbf{3 0 3}$ & $\mathbf{1 0 0 . 0}$ & $\mathbf{1 0 0 . 0}$ & \\
\hline
\end{tabular}

Source: prepared by researchers based on (SPSS) program.

Table 10 shows that the percentage of the sample members who practice administrative work as a department manager reached (25.4\%), the percentage of internal auditors reached $(31.7 \%)$, and the percentage of external auditors reached $(34.3 \%)$, while $(8.5 \%)$ did not mentioned the type of work they practice. The respondents assume positions in the field of business.

Table 11 shows the years of experience of the respondents: 
Table 11. Years of experience

\begin{tabular}{lcccc}
\hline & Frequency & Percent & Valid Percent & Cumulative Percent \\
\hline More than 5 years & 46 & 15.2 & 15.2 & 15.2 \\
More than 10 years & 137 & 45.2 & 45.2 & 60.4 \\
More than15 years & 112 & 37.0 & 37.0 & 97.4 \\
Others & 8 & 2.6 & 2.6 & 100.0 \\
Total & $\mathbf{3 0 3}$ & $\mathbf{1 0 0 . 0}$ & $\mathbf{1 0 0 . 0}$ & \\
\hline
\end{tabular}

Source: prepared by researchers based on (SPSS) program.

Table 11 shows that the years of experience range between 5 years and more than 15 years. $15.2 \%$ have more than 5 years of experience, $45,2 \%$ have more than 10 years of experience. This indicates that the respondents enjoy a significant experience. In addition, $37 \%$ have more than 15 years of experience and $2.6 \%$ have less than 5 years of experience. These percentages are a clear evidence of the great experience that the study sample has.

Table 12 identify the types of professional certificates of the respondents:

Table 12. Professional certifications

\begin{tabular}{lcccc}
\hline & Frequency & Percent & Valid Percent & Cumulative Percent \\
\hline CPA & 50 & 16.5 & 17.5 & 17.5 \\
CIA & 68 & 22.4 & 23.9 & 41.4 \\
LACPA & 51 & 16.8 & 17.9 & 59.3 \\
ACCA & 51 & 16.8 & 17.9 & 77.2 \\
Others & 83 & 27.3 & 22.8 & 100.0 \\
Total & $\mathbf{3 0 3}$ & $\mathbf{1 0 0 . 0}$ & $\mathbf{1 0 0 . 0}$ & \\
\hline
\end{tabular}

Source: prepared by researchers based on (SPSS) program.

Table 12 shows that the respondents are working on developing their skills continuously through assisting trainings. $16.5 \%$ obtained a CPA (Certified Public Accountant), 22.4\% obtained a CIA (Certified Internal Auditor), $16.8 \%$ obtained a (Certified Public Accountant Associate with the Lebanese Association of Certified Public Accountants (LACPA), 16.8\% obtained ACCA (Certified Public Accountant certificate), while a 27.3\% holds other certificates that are not related to accounting or auditing work. These percentages indicate the respondents keep pace with the development in the field of accounting and banking and work on developing their skills.

Table 13. The number of training courses

\begin{tabular}{lcccc}
\hline & Frequency & Percent & Valid Percent & Cumulative Percent \\
\hline 1 to 3 Courses & 110 & 36.3 & 35.4 & 36.4 \\
4 to 6 Courses & 133 & 43.9 & 44.0 & 80.5 \\
More than 7 courses & 43 & 14.2 & 14.2 & 94.7 \\
I did not take courses & 16 & 5.3 & 5.3 & 100.0 \\
Total & $\mathbf{3 0 3}$ & $\mathbf{1 0 0 . 0}$ & $\mathbf{1 0 0 . 0}$ & \\
\hline
\end{tabular}

Source: prepared by researchers based on (SPSS) program.

Table 13 shows that $36.3 \%$ have participated in at least three courses, $43.9 \%$ have participated in 4 to 6 training courses, and $14.2 \%$ have participated in more than 7 training courses, while only a small percentage of $5.3 \%$ have not participated in any course.

Table 14 shows the training courses in which the sample participated:

Table 14. The field of courses you are enrolled in

\begin{tabular}{lcccc}
\hline & Frequency & Percent & Valid Percent & Cumulative Percent \\
\hline Accounting & 111 & 36.6 & 36.6 & 36.6 \\
Auditing & 89 & 29.4 & 29.4 & 66.0 \\
Risk Management & 28 & 9.2 & 9.2 & 75.2 \\
Banking business & 59 & 19.5 & 19.5 & 94.7 \\
Others Specify & 16 & 5.3 & 5.3 & 100.0 \\
Total & $\mathbf{3 0 3}$ & $\mathbf{1 0 0 . 0}$ & $\mathbf{1 0 0 . 0}$ & \\
\hline
\end{tabular}

Source: prepared by researchers based on (SPSS) program. 
Table 14 shows that $36.6 \%$ have participated in accounting courses and the majority are external auditors, $29.4 \%$ have participated in courses related to internal and external auditing, $9.2 \%$ have participated in courses related to risk management, and $19.5 \%$ have participated in courses related to banking, while a percentage of $5.3 \%$ have participated in courses related to other fields.

\subsubsection{Statistical Analysis of the Questionnaire}

\section{Results of the study, analysis and hypothesis testing:}

In this section, the findings of the study will be presented, by answering the study questions, testing the hypotheses using the SPSS program and interpreting the results. The study will determine the extent to which the study hypotheses are accepted or rejected, thus, reach the results explaining the relationship between variables.

\section{Analysis of the study axes:}

The results of the analysis of the first axis: "Lebanese banks apply quality standards in disclosing credit risk".

The results were analyzed by calculating: the arithmetic mean, standard deviation, and the relative weight of the axis paragraphs. The answers were analyzed through (One Sample T-Test), comparing the $\mathrm{T}$ calculated through the SPSS program with the tabular $\mathrm{T}$ and explaining the results regarding the presence of statistical significance in the answers of the respondents.

Table 15. The results of the statistical analysis of the third axis

\begin{tabular}{|c|c|c|c|c|c|c|c|}
\hline & $\mathbf{T}$ & $\begin{array}{c}\text { Sig. } \\
\text { (2-tailed) }\end{array}$ & $\begin{array}{c}\text { Mean } \\
\text { Differe }\end{array}$ & $\begin{array}{c}\text { Relative } \\
\text { Weight }\end{array}$ & $\begin{array}{c}\text { Std. } \\
\text { Deviation }\end{array}$ & Mean & $\mathbf{N}$ \\
\hline $\begin{array}{l}\text { 3.1. The internal auditor realizes the importance of banking risks related } \\
\text { to credits and recognizes the need to improve and develop control } \\
\text { systems to reduce these risks }\end{array}$ & 48.7 & 0.000 & 0.329 & $76.6 \%$ & 1.083 & 3.83 & 303 \\
\hline $\begin{array}{l}\text { 3.2. The internal audit department determines the acceptable level of } \\
\text { credit risks and follows the procedures to reduce risks with the assistance } \\
\text { of management and the risk management department. }\end{array}$ & 54.833 & 0.000 & 0.271 & $75.4 \%$ & 0.979 & 3.77 & 303 \\
\hline $\begin{array}{l}\text { 3.3. The accuracy of forecasting credit risk and the accuracy of } \\
\text { determining its expected results contributes to increasing the level of } \\
\text { accuracy, relevance and reliability of accounting information in } \\
\text { financial reports. }\end{array}$ & 46.168 & 0.000 & 0.318 & $76.4 \%$ & 1.102 & 3.82 & 303 \\
\hline $\begin{array}{l}\text { 3.4. The audit department monitors the ability of credit risk management } \\
\text { to conduct business efficiently and effectively and takes appropriate } \\
\text { measures to identify, measure, monitor and control these risks. }\end{array}$ & 45.071 & 0.494 & 0.065 & $71.2 \%$ & 1.230 & 3.56 & 303 \\
\hline $\begin{array}{l}\text { 3.5. The audit department is committed to implementing the integration } \\
\text { strategy in credit risk management and it works to develop it. }\end{array}$ & 52.201 & 0.241 & 0.106 & $72.2 \%$ & 1.173 & 3.61 & 303 \\
\hline $\begin{array}{l}\text { 3.6. Credit risk management determines target markets, economic } \\
\text { sectors, credit maturity, borrower credit capacity and their adequate } \\
\text { collateral. }\end{array}$ & 48.000 & 0.053 & 0.165 & $73.2 \%$ & 1.104 & 3.66 & 303 \\
\hline $\begin{array}{l}\text { 3.7. Credit risk management takes into account the economic and } \\
\text { financial conditions that may impact the assessment of credits in the } \\
\text { future. }\end{array}$ & 43.967 & 0.012 & -0.052 & $68.6 \%$ & 1.231 & 3.44 & 303 \\
\hline $\begin{array}{l}\text { 3.8. The Audit Department works with the Credit Risk Department on } \\
\text { the periodic assessment of collaterals submitted by the borrowers, to } \\
\text { ensure their ability to repay the debt and reduce credit risk. }\end{array}$ & 47 & 0.001 & 0.229 & $74.6 \%$ & 1.176 & 3.73 & 303 \\
\hline 3. Lebanese banks apply quality standards in disclosing credit risk & 71.278 & 0.001 & 0.177 & $\mathbf{7 3 . 5 \%}$ & 0.6567 & 3.68 & 303 \\
\hline
\end{tabular}

Source: prepared by researchers based on (SPSS) T $(0.05$ ،8) $= \pm 2.306$.

Table 15 shows that:

1) The section that states "The internal auditor realizes the importance of banking risks related to credits and recognizes the need to improve and develop control systems to reduce these risks" reached the highest relative weight amongst the answers, it amounted to (76.6\%). The arithmetic mean reached 3.83, while the calculated "T" value amounted to 48.794 , which is greater than the tabular "T" value at a significance level of 0.05 . These results confirm the existence of a statistically significant relationship in the answers of respondents. Accordingly, we can say that the implementation of quality standards in credit risk disclosure is closely related to the internal audit department's awareness of the credit risk importance and the need to develop control systems to reduce these risks.

2) As for the section "credit risk management takes into account the economic and financial conditions that may impact the assessment of credits in the future.". It ranked eighth and last in terms of the relative 
weight of the answers and amounted to $71.2 \%$. The arithmetic mean of the respondents' answers to the aforementioned section reached 3.56. The calculated "T" value reached 45.071, which is greater than the tabular "T" value at a significance level of 0.05 . These results indicate that there is a statistically significant relationship in the answers of the respondents. Accordingly, we can say that the application of quality standards in the disclosure of credit risks is reasonably related to credit risk management monitoring done by the internal audit department and the implementation of business efficiently and effectively.

In general, from the analysis of the answers of the first axis (Lebanese banks apply quality standards in disclosing credit risk), the arithmetic mean has reached a good percentage of (3.68 out of 5) and the standard deviation reached (0.6567), the relative weight was $(73.5 \%)$, while the calculated " $T$ " value was $(71,278)$, which is greater than the tabular " $\mathrm{T}$ " value at a significance level of 0.05 . This indicates the positive evaluation of the study sample with the questions of the first axis.

Table 16. The statistical significance of the third axis questions

\begin{tabular}{|c|c|c|c|c|c|}
\hline Variable & $\begin{array}{c}\text { Sig. } \\
\text { (1-tailed) }\end{array}$ & & $\begin{array}{l}\text { Mean } \\
\text { Differ }\end{array}$ & Mean & Result \\
\hline $\begin{array}{l}\text { 3.1. The internal auditor realizes the } \\
\text { importance of banking risks related to credits } \\
\text { and recognizes the need to improve and } \\
\text { develop control systems to reduce these risks }\end{array}$ & 0.000 & $\begin{array}{l}\text { The difference is } \\
\text { positive - the } \\
\text { average is greater } \\
\text { than } 3.5\end{array}$ & 0.33 & 3.83 & $\begin{array}{l}\text { The statistical significance is less than } \\
0.05 \text { and the rate is greater than } 3.5- \\
\text { there is a statistical indication that the } \\
\text { rate is greater than } 3.5\end{array}$ \\
\hline $\begin{array}{l}\text { 3.2. The internal audit department determines } \\
\text { the acceptable level of credit risks and } \\
\text { follows the procedures to reduce risks with } \\
\text { the assistance of management and the risk } \\
\text { management department. }\end{array}$ & 0.000 & $\begin{array}{l}\text { The difference is } \\
\text { positive - the } \\
\text { average is greater } \\
\text { than } 3.5\end{array}$ & 0.27 & 3.77 & $\begin{array}{l}\text { The statistical significance is less than } \\
0.05 \text { and the rate is greater than } 3.5- \\
\text { there is a statistical indication that the } \\
\text { rate is greater than } 3.5\end{array}$ \\
\hline $\begin{array}{l}\text { 3.3. The accuracy of forecasting credit risk } \\
\text { and the accuracy of determining its expected } \\
\text { results contributes to increasing the level of } \\
\text { accuracy, relevance and reliability of } \\
\text { accounting information in financial reports. }\end{array}$ & 0.000 & $\begin{array}{l}\text { The difference is } \\
\text { positive - the } \\
\text { average is greater } \\
\text { than } 3.5\end{array}$ & 0.32 & 3.82 & $\begin{array}{l}\text { The statistical significance is less than } \\
0.05 \text { and the rate is greater than } 3.5- \\
\text { there is a statistical indication that the } \\
\text { rate is greater than } 3.5\end{array}$ \\
\hline $\begin{array}{l}\text { 3.4. The audit department monitors the ability } \\
\text { of credit risk management to conduct } \\
\text { business efficiently and effectively and takes } \\
\text { appropriate measures to identify, measure, } \\
\text { monitor and control these risks. }\end{array}$ & 0.247 & $\begin{array}{l}\text { The difference is } \\
\text { positive - the } \\
\text { average is greater } \\
\text { than } 3.5\end{array}$ & 0.06 & 3.56 & $\begin{array}{l}\text { The statistical significance is greater } \\
\text { than } 0.05 \text { and the rate is greater than } \\
3.5 \text { - there is no statistical indication } \\
\text { that the rate is greater than } 3.5\end{array}$ \\
\hline $\begin{array}{l}\text { 3.5. The audit department is committed to } \\
\text { implementing the integration strategy in } \\
\text { credit risk management and it works to } \\
\text { develop it. }\end{array}$ & 0.120 & $\begin{array}{l}\text { The difference is } \\
\text { positive - the } \\
\text { average is greater } \\
\text { than } 3.5\end{array}$ & 0.11 & 3.61 & $\begin{array}{l}\text { The statistical significance is greater } \\
\text { than } 0.05 \text { and the rate is greater than } \\
3.5 \text { - there is no statistical indication } \\
\text { that the rate is greater than } 3.5\end{array}$ \\
\hline $\begin{array}{l}\text { 3.6. Credit risk management determines target } \\
\text { markets, economic sectors, credit maturity, } \\
\text { borrower credit capacity and their adequate } \\
\text { collateral. }\end{array}$ & 0.027 & $\begin{array}{l}\text { The difference is } \\
\text { positive - the } \\
\text { average is greater } \\
\text { than } 3.5\end{array}$ & 0.16 & 3.66 & $\begin{array}{l}\text { The statistical significance is less than } \\
0.05 \text { and the rate is greater than } 3.5- \\
\text { there is a statistical indication that the } \\
\text { rate is greater than } 3.5\end{array}$ \\
\hline $\begin{array}{l}\text { 3.7. Credit risk management takes into } \\
\text { account the economic and financial } \\
\text { conditions that may impact the assessment of } \\
\text { credits in the future. }\end{array}$ & 0.267 & $\begin{array}{l}\text { The difference is } \\
\text { negative - the rate } \\
\text { is smaller than } \\
3.5\end{array}$ & -0.06 & 3.44 & $\begin{array}{l}\text { The statistical significance is greater } \\
\text { than } 0.05 \text { and the rate is greater than } \\
3.5 \text { - there is no statistical indication } \\
\text { that the rate is greater than } 3.5\end{array}$ \\
\hline $\begin{array}{l}\text { 3.8. The Audit Department works with the } \\
\text { Credit Risk Department on the periodic } \\
\text { assessment of collaterals submitted by the } \\
\text { borrowers, to ensure their ability to repay the } \\
\text { debt and reduce credit risk. }\end{array}$ & 0.006 & $\begin{array}{l}\text { The difference is } \\
\text { positive - the } \\
\text { average is greater } \\
\text { than } 3.5\end{array}$ & 0.23 & 3.73 & $\begin{array}{l}\text { The statistical significance is less than } \\
0.05 \text { and the rate is greater than } 3.5 \text { - } \\
\text { there is a statistical indication that the } \\
\text { rate is greater than } 3.5\end{array}$ \\
\hline $\begin{array}{l}\text { 3. Lebanese banks apply quality standards } \\
\text { in disclosing credit risk }\end{array}$ & 0.000 & $\begin{array}{l}\text { The difference is } \\
\text { positive - the } \\
\text { average is } \\
\text { greater than } 3.5\end{array}$ & 0.18 & 3.68 & $\begin{array}{l}\text { The statistical significance is less } \\
\text { than } 0.05 \text { and the rate is greater than } \\
3.5 \text { - there is a statistical indication } \\
\text { that the rate is greater than } 3.5\end{array}$ \\
\hline
\end{tabular}

Source: prepared by researchers based on (SPSS).

From Table 16, the following has been noted:

Testing the hypotheses and the answer to the first axis questions:

The first hypothesis: 
- H1: There is a statistically significant relationship between expectations of credit risk and the quality of disclosure in the annual financial reports.

- Ho: There isn't a statistically significant relationship between expectations of credit risk and the quality of disclosure in the annual financial reports.

Table 17. The significance of the simple regression equation regarding the impact of credit risks on the quality of disclosure in the annual financial reports

\begin{tabular}{|c|c|c|c|c|c|c|c|c|c|}
\hline \multirow{2}{*}{$\begin{array}{l}\text { Dependent variable: } \\
\text { Quality of disclosure in the } \\
\text { annual financial reports }\end{array}$} & \multicolumn{2}{|c|}{$\begin{array}{l}\text { Unstandardized } \\
\text { Coefficients }\end{array}$} & \multirow{2}{*}{$\begin{array}{c}\begin{array}{c}\text { Standardized } \\
\text { Coefficient }\end{array} \\
\text { Beta } \\
\end{array}$} & \multicolumn{2}{|c|}{ T-Test } & \multicolumn{2}{|c|}{$\mathbf{F}$} & \multicolumn{2}{|c|}{$\mathbf{R}$} \\
\hline & B & Std. Error & & $\mathbf{T}$ & Sig & $\mathbf{F}$ & Sig & $\mathbf{R}$ & $\mathbf{R}^{2}$ \\
\hline Independent variable & .506 & .192 & & 2.373 & .018 & & & & \\
\hline Credit Risk & .862 & .054 & .742 & 19.207 & .000 & 22.205 & .000 & .742 & .551 \\
\hline & & & & & Level & 0.05 & & & $\mathbf{N}=\mathbf{3 0 3}$ \\
\hline
\end{tabular}

Source: Prepared by researchers.

Table 17 shows:

- The impact of credit risk on the quality of the disclosure in the annual financial reports: the correlation coefficient between the independent variable "credit risk" and the dependent variable "quality of disclosure in the annual financial reports" reached 0.742 . This indicates a strong positive correlation between the two variables. The value of the coefficient of determination, which is the value that expresses the amount of variance highlighted by the dependent variable, "Quality of Disclosure in Annual Financial Reports", reached 0.551 . Consequently, the independent variable succeeded in highlighting $55 \%$ of the change in the dependent variable, while the rest is due to other factors that were not taken into account.

- The calculated $\mathrm{F}$ value is equal to 22.205 , which is greater than the tabular $\mathrm{F}$ value of (2.10). This value is large at a significance level of 5\%. It indicates that the model is highly significant.

- The value of the regression coefficient is equal to 0.862 . This value highlights the impact of credit risks on the quality of disclosure in the annual financial reports. To verify the significance of this impact, the calculated "T" test value was equal to 19.207, which is greater than the value of tabular " $T$ " at a significance level of 0.05 . The results of the regression analysis confirm that the probability value of the " $\mathrm{T}$ " test $(\mathrm{Sig}=0.000)$ is less than the level of significance $(\alpha=0.05)$, indicating the presence of a significant effect, which proves the hypothesis' validity. Thus, we conclude that:

There is a significant impact of credit risks on the quality of disclosure in the annual financial reports; it amounts amount $86.2 \%$.

Decision It is possible to accept the alternative assumption and the rejection of the zero assumption, and deduct that forecasting credit risks leads to achieving quality in disclosure in the annual financial reports.

This means that the hypothesis $\mathrm{H} 0$ is rejected and the hypothesis $\mathrm{H} 1$ is accepted, and thus, we conclude:

"Banks in Lebanon are aware of the importance of forecasting credit risk and its relationship to the quality of disclosure in the annual financial reports."

$$
Y=0.862 X+0.506
$$

The effect of credit risk on the quality of disclosure in annual financial reports can be formulated as follows:

Equation (1): Impact of credit risk on the quality of disclosure in annual financial reports:

\section{Whereas:}

Y: Quality of disclosure in annual financial reports.

$\mathbf{X}$ : Credit risk.

The results of the analysis of the second axis "Lebanese banks apply quality standards in disclosing operational risks"

The results were analyzed by computing the arithmetic mean, standard deviation, and the relative weight of the axis sections. The answers were analyzed through (One-Sample T-Test), through comparing the T calculated with the tabular T through the SPSS program and explaining the results of the sample's answers in terms of the presence of statistical significance. 
Table 18. The results of the statistical analysis of the third axis

\begin{tabular}{|c|c|c|c|c|c|c|c|}
\hline & $\mathbf{T}$ & $\begin{array}{c}\text { Sig. } \\
(2-\text { tailed })\end{array}$ & $\begin{array}{c}\text { Mean } \\
\text { Differe }\end{array}$ & $\begin{array}{c}\text { Relative } \\
\text { Weight }\end{array}$ & $\begin{array}{c}\text { Std. } \\
\text { Deviation }\end{array}$ & Mean & $\mathbf{N}$ \\
\hline $\begin{array}{l}\text { 5.1. There is cooperation between the Internal Audit Department and } \\
\text { the Risk Management Department in order to exchange information } \\
\text { related to operational risks. }\end{array}$ & 44.555 & 1.000 & 0.000 & $70.0 \%$ & 1.208 & 3.50 & 303 \\
\hline $\begin{array}{l}\text { 5.2. The Internal Audit Department assesses the banking future } \\
\text { services to reduce the risks associated with it } \\
\text { 5.3. The bank adopts a specific strategy for managing operational }\end{array}$ & 46.675 & 0.111 & -0.153 & $67.0 \%$ & 1.246 & 3.35 & 303 \\
\hline risks. & 45.053 & 0.376 & 0.082 & $71.6 \%$ & 1.210 & 3.58 & 303 \\
\hline $\begin{array}{l}\text { 5.4. There is a separation of responsibilities between operational risk } \\
\text { management and the audit authorities. }\end{array}$ & 49.318 & 0.001 & 0.294 & $75.8 \%$ & 1.087 & 3.79 & 303 \\
\hline $\begin{array}{l}\text { 5.5. The operational risk management structure is subject to an } \\
\text { effective, comprehensive, independent, efficient and trained internal } \\
\text { audit function. }\end{array}$ & 51.761 & 0.005 & 0.241 & $74.8 \%$ & 1.111 & 3.74 & 303 \\
\hline $\begin{array}{l}\text { 5.6. The Bank uses self-assessment tools, risk indicators and risk } \\
\text { surveys to identify and evaluate operational risks. }\end{array}$ & 49.550 & 0.003 & 0.265 & $75.2 \%$ & 1.158 & 3.76 & 303 \\
\hline $\begin{array}{l}\text { 5.7. The operational risks that the bank may face are identified and } \\
\text { defined. }\end{array}$ & 42.277 & 0.874 & 0.018 & $70.4 \%$ & 1.444 & 3.52 & 303 \\
\hline $\begin{array}{l}\text { 5. Lebanese banks apply quality standards in disclosing } \\
\text { operational risks }\end{array}$ & 74.051 & 0.060 & 0.10672 & $72.11 \%$ & 0.73385 & 3.606 & 303 \\
\hline
\end{tabular}

Source: Prepared by researcher based on SPSS.

Table 18 shows that:

1). The section that states "there is a separation of responsibilities between the operational risk management and the auditing bodies" reached the highest relative weight amongst the answers, it amounted to $75.8 \%$. The arithmetic mean of the answers to the aforementioned section reached (3.79), while the calculated "T" value reached (49.318), which is greater than the tabular "T" value at a significance level of 0.05 . Consequently, there is a statistically significant relationship in the answers. We can say that the implementation of quality standards in the disclosure of operational risks is linked to the separation of responsibilities between the operational risk management and the auditing bodies.

2). As for the section " the Internal Audit Department assesses the banking future services to reduce the risks associated with it" came in seventh with a relative weight of (67.0\%), and an arithmetic mean of (3.35), which is below average. The calculated "T" value was (46.675), which is greater than the tabular "T" value at a significance level of 0.05 . Consequently, there is a statistically significant relationship in the responses, and accordingly, we can say that the implementation of quality standards in the disclosure of operational risks is related to some extent to the assessment of the bank future services by the internal audit department.

In general, from the analysis of the responses of the fifth axis, "Lebanese banks apply quality standards in disclosing operational risks", it appears that the arithmetic mean is (3.606 out of 5), which is considered a high percentage of the mean, and the standard deviation is $(0.7738)$. The relative weight reached $(72.11 \%)$. The calculated " $T$ " value is equal to (74.051), which is greater than the tabular " $T$ " value at a significance level of 0.05 . This confirms the positive evaluation of the study sample with the questions of the third axis.

Testing hypotheses and answering the questions of the third axis: The third hypothesis:

- H0: There isn't a statistically significant relationship between forecasting operating risks and the quality of disclosure in the annual financial reports.

- H1: There is a statistically significant relationship between forecasting operating risks and the quality of disclosure in the annual financial reports.

Table 19. The significance of the simple regression equation regarding the impact of operating risks on the quality of disclosure in the annual financial reports

\begin{tabular}{|c|c|c|c|c|c|c|c|c|c|}
\hline \multirow{2}{*}{$\begin{array}{l}\text { Dependent variable: } \\
\text { Quality of disclosure in the annual } \\
\text { financial reports }\end{array}$} & \multicolumn{2}{|c|}{$\begin{array}{c}\text { Unstandardized } \\
\text { Coefficients } \\
\end{array}$} & \multirow{2}{*}{$\begin{array}{c}\begin{array}{c}\text { Standardized } \\
\text { Coefficient }\end{array} \\
\text { Beta }\end{array}$} & \multicolumn{2}{|c|}{ T-Test } & \multicolumn{2}{|c|}{$\mathbf{F}$} & \multicolumn{2}{|c|}{$\mathbf{R}$} \\
\hline & B & $\begin{array}{c}\text { Std. } \\
\text { Error }\end{array}$ & & $\mathbf{T}$ & Sig & $\mathbf{F}$ & Sig & $\mathbf{R}$ & $\mathbf{R}^{2}$ \\
\hline The Independent & .102 & .214 & & .467 & .000 & \multirow{2}{*}{18.155} & \multirow{2}{*}{.000} & \multirow{2}{*}{.678} & \multirow{2}{*}{.460} \\
\hline Operational risk & .975 & .062 & .678 & 16.016 & .000 & & & & \\
\hline & & & & \multicolumn{4}{|c|}{ 0.05 Level } & \multicolumn{2}{|c|}{$303=N$} \\
\hline
\end{tabular}


Source: Prepared by researchers $2.365 \pm=(7,0.05) \mathrm{T}$, the tabular value of " $t$ " at a significance level of 0.05 .

The table shows that:

- The impact of operational risks on the quality of disclosure in the annual financial reports: the correlation coefficient between the independent variable "operating risk" and the dependent variable "quality of disclosure in the annual financial reports" reached (0.678), indicating the strong positive relationship between the two variables. The value that expresses the variance highlighted by the dependent variable, "Quality of Disclosure in Annual Financial Reports" reached (0.460). Consequently, the independent variable succeeded in highlighting $46 \%$ of the change in the dependent variable, while the rest is due to other factors that were not taken into consideration.

- The calculated $F$ value is equal to (18.155), which is greater than the tabular F value of (2.14), This value is large at a significance level of $5 \%$, indicating that the model is highly significant.

- The value of the regression coefficient is equal to (0.975). This value highlights the impact of operating risks on the quality of disclosure in the annual financial reports. To verify the significance of this impact, the calculated " $T$ " test value was equal to (16.016) which is greater than the value of tabular " $T$ " at a significance level of 0.05 .

The results of the regression analysis confirm that the probability value of the "T" test $(\mathrm{Sig}=0.000)$ is less than the level of significance $(\alpha=0.05)$, indicating the presence of a significant impact, which proves the hypothesis' validity. Thus, we conclude that there is a very significant impact of operational risks on the quality of disclosure in the annual financial reports, and it amounts to $97.5 \%$.

Decision: It is possible to accept the alternative hypothesis and reject the zero hypothesis, and then say that the forecasting operational risks leads to achieving quality in the disclosure in the annual financial reports.

Consequently, that hypothesis $\mathrm{H} 0$ is rejected and hypothesis $\mathrm{H} 1$ is accepted, thus we conclude:

"Banks in Lebanon are aware of the importance of forecasting operational risks and its impact on the quality of disclosure in the annual financial reports."

The impact of operational risk on the quality of disclosure in the annual financial reports can be formulated as follows:

Equation (2): The impact of operational risks on the quality of disclosure in the annual financial reports.

$$
Y=0.975 X+0.102
$$

\section{Whereas:}

Y: Quality of disclosure in annual financial reports.

$\mathbf{X}$ : Operational risk.

Summary of the results:

Upon the completion of the statistical analysis, and in order to confirm the results and the correlation of the hypotheses with the result of tests, we conclude the following:

- The study showed a high level of approval for the first axis "Lebanese banks apply quality standards in disclosing credit risk". The arithmetic mean for this axis reached (3.68) and the standard deviation reached (0.65).

- The study showed a high level of approval for the second axis "Lebanese banks apply quality standards in disclosing operational risks". The arithmetic mean for this axis reached (3.6) and standard deviation reached $(0.73)$.

Below are the results of the axes questions stated in Table 20 that show the hypothesis and the results of the $\mathrm{T}$-Test, and the final result of the test (R).

Table 20. The hypotheses, statistical results and results for these hypotheses

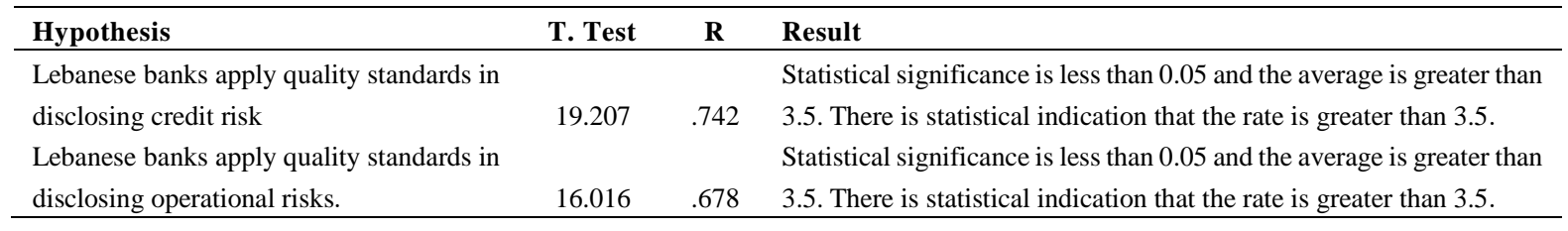


Source: Prepared by the researcher based on the analytical tables.

\section{Conclusion \& Recommendations}

\subsection{Conclusions}

The study reached a set of conclusions, which are the following:

- Several economic institutions, especially banks, had sought to find mechanisms and set plans to reduce financial risks. They endeavored to find means and tools to control, plan and forecast all activities, in order to avoid losses and preserve the sustainability of activities and the rights of shareholders and stakeholders. The cooperation between the departments of risk management and internal audit aims at ensuring the good management of banks. This latter leads to preserve the interests of all parties, limit improper procedures, inspire the role of the board of directors and apply disclosure and transparency controls to achieve financial and economic reform in the country and build institutional systems that rely on control mechanisms in business.

- Banks started relying on the risk management department in an attempt to control the risks facing the banking business, especially with the rapid development of the financial and banking systems worldwide. Banks also started working on the coordination and cooperation between the rest of the departments, especially those concerned with the audit process, in order to develop and improve the performance of workers and employees in this context.

- In fact, cooperation succeeds when the management is aware of the important impact of these departments, and the role they play in the proper implementation of business and the control of risks.

- The audit department is aware of the importance of risk management in banks, the importance of developing audit procedures that take risks into account, and the importance of its role in stimulating the financial risk management role in commercial banks.

- The work of the internal auditor related to financial risk management aims to confirm the validity, reliability and relevance of the financial statements and the internal control system.

- Banks are exposed to many risks (financial, operational and market risks in addition to the risks of operations related to interest and credit) that affect the performance of banking business. In this regard, the internal auditor plays an important role. He/ She cooperate with the management to implement an effective system of internal control to reduce and control the risks and reduce the negative impact on the financial position of the bank.

- Cooperation between the Internal Audit Department, the Board of Directors, and the Executive Management is of great importance in conducting the risk management in commercial banks.

- $\quad$ Auditor shall perform the data analysis procedures with due diligence for the proper implementation of risk management processes.

- New and advanced audit mechanisms and methods are implemented to detect deficiencies in the internal control and internal control systems in banks.

- The internal audit department monitors and evaluates the bank's risk management system to achieve the bank's objectives and reduce potential losses.

- The internal audit department in banks provides information to the Board of Directors, to take decisions and assist in the examination and evaluation of the risk management system.

- The internal audit department provides advice and information to the risk management department in banks, but it is not responsible of the daily tasks

\subsection{Recommendations}

In order to implement the disclosure rules in line with the development of their financial performance, banks shall:

- Enhance the efficiency and effectiveness of the risk management and internal audit departments and ensure their cooperation, facilitate the work of the external auditor through applying international accounting and auditing standards and their amendments related to the banking sector, and apply the best practices regarding modern financial methods. This contributes to the growth of banks, increases their profitability and reduces the risks, especially that the impact of the audit process on the management of financial risks leads to control the risks in the banking business, and consequently, reduce the risks and their negative results and turn the threats into an opportunity to grow. 
- Have good governance that requires controlling the practices and behaviors of people in charge. This can be done through adhering to the supervisory and audit procedures and allowing the bank to self-monitor its activities, in order to reduce potential risks.

- $\quad$ Promote justice, transparency and fair treatment of all parties, including shareholders, investors and other stakeholders.

- Specify in detail the tasks, responsibilities and duties of each member of the board of directors and the executive management, as well as the powers and authorities that are delegated to the executive management.

- Define their own organizational structure, especially in terms of the internal auditing department and the risk management department, so that this structure reflects the balance between powers and authorities and the separation between the board of directors and the executive management.

- Ensure periodically and continuously the efficiency of the internal auditing and control systems, which cover all activities. In fact, the internal audit systems aim at maintaining the bank's financial integrity, the accuracy of its data, and the efficiency of its operations from various aspects.

- Support the social role of banks and inciting them to play a more effective social role, by expanding the scope of social activities in addition to its basic and main activities. For instance, the bank can implement or support scientific research that benefits the environment.

- Pay more attention to the monitoring and coordinating the departments of risk management and internal auditing in commercial banks, as it leads to a positive impact on various aspects of banking performance.

- Continue to work towards promoting continuous learning, through intensification of courses and conferences related to risk management. Continuing education leads to obtaining renewable skills in banking, and keeping pace with the rapid development in the financial and banking business of internal auditors, in order to keep pace with development of the banking business and to conduct and simplify the process of risk management.

- Monitor the developments of audit standards and their relationship to risk management.

- Work on strengthening the elements of the internal auditors work continuously to be able to carry out their duties to the fullest.

- Highlight the necessity of having a guide to manage the risks faced by banks in the light of the developments in the banking field.

- Merge of Lebanese banks, as the number of banks operating and registered in Lebanon currently is about 43 with approximately 1,100 branches on Lebanese territory, while the population does not exceed 4.5 million people and the geographical area does not exceed 10,452 km2.

- $\quad$ Raise the value of deposit insurance (the Deposit Insurance Authority) since it protects the bank and satisfy the interests of depositors.

- $\quad$ Limit the powers of the Governor of Banque du Liban, and delegating some powers to the Central Council.

- Separate some of the functions performed by the Director General of the Ministry of Finance, in the Central Bank, the Ministry, and the Central Council because of the conflict of interest.

- Issue a circular from Banque du Liban to the banks, requesting the determination of the value of the banks' funds in the correspondent banks.

- Increase the capital of commercial banks in Lebanon, by capitalizing a percentage of the profits for several years to come, in order to reassure customers and restore confidence in the banking sector.

\section{References}

Abu Zaid, M. (2011). International Accounting and its Repercussions on Arab Countries. Al-Marikh Publishing House, Riyadh, Saudi Arabia.

Abu, H., \& Majid, I. (2009). The impact of applying corporate governance rules on accounting disclosure and the quality of financial reports: A field study on companies listed on the Palestine Stock Exchange. Unpublished Master's Thesis, The Islamic University, Gaza, and Palestine.

Abu, N. M., \& Hamidat, J. (2008). International Accounting and Financial Reporting Standards: Theoretical and Scientific Aspects. Amman, Jordan: Wael Publishing House. 
Ahrens, A. A., \& Loebbecke, J. K. (1991). Auditing, an integrated approach. Englewood Cliffs, N.J: Prentice Hall

Al Jaarat, K. J. (2008). International Financial Reporting Standards 2007 \& IASS (1st ed.). Ithraa for Publishing and Distribution, Sharjah (Oman) University Library.

Al-Matarneh, G. F. (2013). Introduction to Contemporary Account Auditing (1st ed.). Amman, Jordan: Zamzam Publishers and Distributors.

Al-Sabban, M. S. et al. (2013). Accounting Measurement and Analysis. House of University Education for Printing, Publishing and Distribution: Alexandria, Egypt.

Al-Sisi, S. El-Din. H. (2014). Global Economy and Economic Crises: Causes, Repercussions, and Ways of Confrontation. International Economic Encyclopedia, al Kitab al Hadith Publishing House.

Alvin, J. (2005). Auditing an Integrated Approach. New Jersey: Printing Hall.

Banque du Liban, Banking Control Commission, Memo No. 18/2015, Beirut, 13/8/2015.

DE Fond, M., \& Zhang, J. (2014). A Review of Archival Auditing Research. Journal of Accounting and Economics, 58. https://doi.org/10.1016/j.jacceco.2014.09.002

Hamada, R. (2013). Measuring the effect of voluntary disclosure on the quality of financial reports: A field study at the Amman Stock Exchange. The Jordanian Journal of Business Administration, (10).

Hamdan, A. M. M. (2011). The impact of accounting conservatism in improving the quality of financial reports: An empirical study on Jordanian Public Joint Stock Industrial Companies. Administrative Sciences, 38.

International Auditing and Assurance Standards Board. (2012). Standards on Quality Control. International Auditing Publications.

International Financial Reporting Standards. (2018). Arab Society of Certified Accountants. Amman, Jordan: Talal Abu-Ghazaleh Organization.

Jizi, M. I., \& Dixon, R. (2017). Are Risk Management Disclosures Informative or Tautological? Evidence from the U.S. Banking Sector. Accounting Perspectives, 16(1), 7-30. https://doi.org/10.1111/1911-3838.12134

Joma'a, A. H. (2009). The Introduction to Modern Auditing. Amman, Jordan: Al-Safaa for Publishing and Distribution.

Joma'a, A. H. (2011). Institutional Control and Development Dimensions for Professional Practices Framework for Internal Auditing. Amman, Jordan: Al-Arauna Publishing House.

Mario, C. (2011). U.K. Auditor's Criticized on Bank. Wall Street Journal.

Muhammad, S. W. (2008). The Practical Implementation of Financial Reports and Disclosures in accordance with International Accounting Standards. Association of Certified Public Accountants in Lebanon, Beirut.

Qarun, A. (2013). The Algerian banks' commitment to the application of capital adequacy in accordance with the recommendations of the Basel Committee. Unpublished Master's Thesis, Faculty of Economic, Commercial and Administrative Sciences, Sétif University.

Roman, L. W. (2010). Financial Accounting an Introductions to Concepts, Methods, and Uses (13th ed., p. 7) Southwestern, Engage Learning, USA.

Sobh, D. Y., \& Sobh, B. D. (2014). Auditing Financial Statements: Auditing Accounts from the Theoretical and Applied Perspectives (Part 2). Beirut, Lebanon.

Tasios, S., \& Bekiaris, M. (2012). Auditor's Perceptions of Financial Reporting Quality: The Case of Greece. International Journal of Accounting and Financial Reporting, 2. https://doi.org/10.5296/ijafr.v2i1.1286

Wahba, M. S., \& Jebai, M. M. (2012). International Auditing Standards and Challenges of Implementing Peer Review. Beirut: Kalimat for Publishing and Distribution.

\section{Copyrights}

Copyright for this article is retained by the author(s), with first publication rights granted to the journal.

This is an open-access article distributed under the terms and conditions of the Creative Commons Attribution license (http://creativecommons.org/licenses/by/4.0/). 